\title{
O HOMEM DUPLICADO À LUZ DE ESPELHOS BORGIANOS: DO DIALOGISMO AO ABSURDO
}

\author{
Diego Gomes do Valle
}

Submetido em 24 de maio de 2018.

Aceito para publicação em 29 de agosto de 2018.

Cadernos do IL, Porto Alegre, n. ${ }^{\circ}$ 57, novembro, p. 112-124

\section{POLÍTICA DE DIREITO AUTORAL}

Autores que publicam nesta revista concordam com os seguintes termos:

(a) Os autores mantêm os direitos autorais e concedem à revista o direito de primeira publicação, com o trabalho simultaneamente licenciado sob a Creative Commons Attribution License, permitindo o compartilhamento do trabalho com reconhecimento da autoria do trabalho e publicação inicial nesta revista.

(b) Os autores têm autorização para assumir contratos adicionais separadamente, para distribuição não exclusiva da versão do trabalho publicada nesta revista (ex.: publicar em repositório institucional ou como capítulo de livro), com reconhecimento de autoria e publicação inicial nesta revista.

(c) Os autores têm permissão e são estimulados a publicar e distribuir seu trabalho online (ex.: em repositórios institucionais ou na sua página pessoal) a qualquer ponto antes ou durante o processo editorial, já que isso pode gerar alterações produtivas, bem como aumentar o impacto e a citação do trabalho publicado.

(d) Os autores estão conscientes de que a revista não se responsabiliza pela solicitação ou pelo pagamento de direitos autorais referentes às imagens incorporadas ao artigo. A obtenção de autorização para a publicação de imagens, de autoria do próprio autor do artigo ou de terceiros, é de responsabilidade do autor. Por esta razão, para todos os artigos que contenham imagens, o autor deve ter uma autorização do uso da imagem, sem qualquer ônus financeiro para os Cadernos do IL.

\section{POLÍTICA DE ACESSO LIVRE}

Esta revista oferece acesso livre imediato ao seu conteúdo, seguindo o princípio de que disponibilizar gratuitamente o conhecimento científico ao público proporciona sua democratização. 


\title{
O HOMEM DUPLICADO À LUZ DE ESPELHOS BORGIANOS: DO DIALOGISMO AO ABSURDO $O$ HOMEM DUPLICADO IN THE LIGHT OF BORGIAN MIRRORS: FROM DIALOGISM TO ABSURD
}

Diego Gomes do Valle*

\begin{abstract}
RESUMO: O presente artigo buscar analisar o romance O homem duplicado, do português José Saramago, trazendo temas e passagens paralelas dos contos e ensaios do argentino Jorge Luis Borges. Este intento se justifica na medida em que o escritor argentino sempre se utilizou da temática do duplo em seus escritos, fato que nos autorizou, esperamos, a estabelecer conexões com a prosa do escritor argentino. Para além disso, teóricos como Mikhail Bakhtin, Louis Lavelle, Paul Ricoeur e Jean Pouillon nos auxiliaram a prolongar o alcance das reflexões propostas no romance ora compulsado. Desta forma, almejamos ter construído uma leitura do romance prolífica e disseminadora de sentidos.
\end{abstract}

PALAVRAS-CHAVE: Jorge Luis Borges; José Saramago; O homem duplicado.

ABSTRACT: This article seeks to analyze the novel O homem duplicado, by the Portuguese José Saramago, bringing themes and parallel passages from the tales and essays of the Argentine Jorge Luis Borges. This attempt is justified inasmuch as the argentine writer has always used the theme of the double in his writings, a fact that authorized us, we hope, to establish connections with the prose of the Argentine writer. Moreover, theorists such as Mikhail Bakhtin, Louis Lavelle, Paul Ricoeur, and Jean Pouillon helped us to extend the scope of the reflections proposed in the novel here. In this way, we hope to have constructed a prolific reading of the novel and disseminating of senses.

KEYWORDS: Jorge Luis Borges; José Saramago; O homem duplicado.

\section{Introdução}

"El hombre de ayer ha muerto en el de hoy, el de hoy muere en el de mañana".

Plutarco apud Jorge Luis Borges, "Nueva refutación del tiempo".

O presente artigo almeja aproximar as questões identitárias presentes no romance $O$ homem duplicado (2008), de José Saramago, ao universo temático e filosófico de Jorge Luis Borges. Um intento, é mister que se diga, ensaístico na essência, pois flerta continuamente com o proliferação de sentidos, ao invés da busca de uma chave exegética pretensamente totalizante.

A trama da personagem Tertuliano Máximo Afonso parece saída de um conto de Borges, pois, como se sabe, o duplo foi um dos temas mais frequentados pelo escritor argentino, além de seu interesse especular, que não deixa de ser outra forma de duplicação: "los espejos y la cópula son abominables, porque multiplican los hombres" (BORGES, 1980a, p.409) ${ }^{29}$, dirá um heresiarca de Tlön.

\footnotetext{
* Doutor em Teoria e História Literária (UNICAMP). Atualmente, Professor Colaborador da UEPG.

29 "Os espelhos e a cópula são abomináveis, porque multiplicam os homens".
} 
Para além das relações com a obra contística e ensaística de Borges, buscaremos em Mikhail Bakhtin, e em outros pensadores, posições que possam iluminar o drama identitário contido no romance de Saramago, seja pela via da reflexão filosófica, seja pela análise comparativa com outros textos ficcionais. Especialmente, Bakhtin merece destaque, porque suas teorias da linguagem, do romance e - por que não? - teoria ontológica, nunca deixam escapar a mirada do outro, a presença inescapável do outro no ser. Não à toa, o pensador russo discorrerá, como veremos, precisamente sobre o duplo e seus reflexos no discurso do romance.

Desta forma, cremos que o jogo metaficcional apresentado em $O$ homem duplicado possa encontrar ressonância nesses nomes escolhidos, bem como produzir mais sentidos possíveis no diálogo ficcional borgiano. Se a metaficção nos lembra constantemente que o que lemos é um mundo de papel, "El mundo, según Mallarmé, existe para un libro; según Bloy, somos versículos o palabras o letras de un libro mágico, y ese libro incesante es la única cosa que hay en el mundo: es, mejor dicho, el mundo" (BORGES, 1980b, p. 233) ${ }^{30}$.

Desta forma, no diálogo especular destes dois mundos, físico e de papel, do leitor e dos personagens, um drama profundamente absurdo, mas humano, vai se deslindando. Eis o que nos espera.

\section{Reflexões especulares em torno do duplo}

"às vezes tenho até a impressão de não saber exatamente o que sou, sei quem sou, mas não o que sou, não sei se me faço explicar"

José Saramago, O homem duplicado.

É inegável que o tema duplo ocupa grande parte da contística de Borges, em suas múltiplas possibilidades de representação. "Los teólogos" colocam os dois estudiosos da Igreja que disputam avidamente o posto de maior defensor da fé, ao mesmo tempo em que o outro seria o herege a ser queimado. "Pierre Menard, el autor del Quijote", o primeiro grande conto escrito por Borges, trata deste Menard que quer, desafiando o princípio de identidade, ser efetivamente Cervantes, deseja tudo quanto desejava o escritor espanhol. Do mesmo modo, "La busca de Averroes" ilustra o filósofo árabe que, "encerrado en el ámbito del Islám", nunca pode saber o que Aristóteles quis dizer com "tragédia" e "comédia" (apesar de ter se desdobrado no Estagirita o quanto foi possível). "Tres versiones de Judas" coloca o traidor e o redentor como um duplo necessário para o Cristianismo, posto que um necessariamente precisava ser o "criminoso odioso" para sacrificar o imaculado "bode expiatório": "Judas buscó el infierno, porque la dicha del Señor le bastaba" (BORGES, 1980a, p. $518)^{31}$. Neste caso, Cristo e Judas acabam sendo um mesmo ato da Divindade, sendo complementares e unos na eternidade: "En el paraíso, Aureliano supo que para la insondable divinidad, él y Juan de Panonia (el ortodoxo y el hereje, el aborrecedor y el

\footnotetext{
30 “O mundo, segundo Mallarmé, existe para um livro; segundo Bloy, somos versículos ou palavras ou letras de um livro mágico, e esse livro incessante é a única coisa que há no mundo: ou, melhor dizendo, é o mundo".

31 "Judas buscou o Inferno, porque a fortuna do Senhor lhe bastava".
} 
aborrecido, el acusador y la víctima) formabam una sola persona" (BORGES, 1980b, p. 37) ${ }^{32}$, diz o narrador de "Los teólogos".

No conto "Tema del traidor y del héroe", o traidor, Fergus Kilpatrick, foi um conspirador durante as rebeliões em prol da independência irlandesa. Para morrer como herói, e manter a causa libertária viva, é morto e redimido (verdadeiro algoz e bode expiatório de si mesmo) repetindo cenas de Macbeth e Júlio César, como se o mundo fosse um grande teatro: "El condenado entró em Dublín, discutió, obró, rezó, reprobó, pronunció palabras y cada uno de esos actos que reflejaría la gloria, había sido prefijado por Nolan. Centenares de actores colaboraron con el protagonista; el rol de algunos fue complejo; el de otros, momentáneo" (BORGES, 1980a, p. 495) ${ }^{33}$.

Esta lista, não exaustiva, já é suficiente para ilustrar o interesse borgiano pelo duplo. Cada conto traz uma nuança identitária que só é possível quando o outro diante do eu é, precisamente, o mesmo. Daí a analogia com o espelho, objeto tão caro a Borges: "Tanto quanto o estranho que, em certos instantes, vem ao nosso encontro num espelho, o irmão familiar e no entanto inquietante que encontramos nas nossas próprias fotos também é o absurdo" (CAMUS, 2005, p. 29). Eis a mesma sensação de absurdo que Tertuliano Máximo Afonso experimenta quando vê o recepcionista de hotel do filme Quem Porfia Mata Caça e exclama: "Sou eu". Dezenas de páginas adiante, no primeiro encontro com Daniel Santa-Clara/António Claro, o narrador se utiliza da metáfora especular para anunciar a ambos: "a voz de ambos irá repetir-se como um espelho se repete diante de outro espelho" (SARAMAGO, 2008, p. 157). Um espelho diante de outro, como se sabe, gera uma matriz infinita de imagens que se repetem, o que, por sua vez, acaba por obnubilar a ideia de origem, de primazia, de unidade: "de cada vez que se olhar num espelho nunca terá a certeza de que se o que o está vendo é a sua imagem virtual, ou a minha imagem real" (SARAMAGO, 2008, p. 158). Eis o absurdo, diria Albert Camus.

A perturbadora sensação de dúvida, diante da natureza da matéria que compõe seu reflexo, traz um questionamento existencial profundo: se duvido que sou eu diante de meus olhos, passo a me questionar logo em seguida: “quem sou eu?". Ou seja, se a consciência não consegue precisar minimamente seu status ontológico, passa a relativizar sua própria legitimidade ("Somos e não somos nós", como o Alferes Jacobina, de Machado de Assis, já percebera). O filósofo Louis Lavelle, em $O$ erro de Narciso, diz que:

\footnotetext{
Ninguém pode se reconhecer inteiramente na efígie que o espelho da reflexão nos devolve. Somos e não somos nós. Seja qual for a precaução com que Narciso se duplica, ele enfrenta a si mesmo e faz aparecer diante dele uma imagem invertida e complementar. É esse diálogo permanente do eu e de sua imagem que constitui as alternativas mesmas da consciência que temos da vida. E o eu jamais obtém com a imagem aquela exata coincidência que aboliria ambos (LAVELLE, 2012, p. 42).
}

Claro está, espelho e duplo não são a mesma coisa, mas se aproximam na medida em que, no ente de ficção assim representado, produzem um mesmo e perturbador efeito: “Assim nos vemos como um outro que, no entanto, não é um outro, que nos dá de nós mesmos somente uma aparência que nem a mão pega, nem o espelho

\footnotetext{
32 "No paraíso, Aureliano soube que para a insondável divindade, ele e Juan de Panonia (o ortodoxo e o herege, o aborrecedor e o aborrecido, o acusador e a vítima) formavam uma só pessoa".

33 “O condenado entrou em Dublin, discutiu, obrou, rezou, reprovou, pronunciou palavras e cada um desses atos, que refletiria a glória, havia sido prefixado por Nolan. Centenas de atores colaboraram com o protagonista; o rol de alguns foi complexo; o de outros, momentâneo".
} 
retém, e uma falsa aparência que sempre trai o modelo" (LAVELLE, 2012, p. 42). Tal é, fenomenologicamente, nossa experiência especular. Em termos espaciais, Foucault praticamente diz o mesmo: "O espelho, afinal, é uma utopia, pois é um lugar sem lugar" (FOUCAULT, 2003, p. 415).

Com a descoberta do duplo, Tertuliano passa a se contemplar esteticamente, pois a si mesmo trata-se como um outro, como um objeto fora de si, mas que ainda participa do eu que contempla. A partir desse momento, deixa de viver e passa a olhar-se, passa a ter uma vida estritamente estética. Diz, novamente, Louis Lavelle em seu Erro de Narciso:

[Narciso] quer ser o espectador de si mesmo, ou seja, desse ato interior pelo qual não cessa de nascer para a vida e que nunca pode ser um espetáculo sem se aniquilar. Ele se olha em vez de viver, o que é seu primeiro pecado. Busca sua essência e encontra apenas sua imagem, que não cessa de decepcioná-lo (LAVELLE, 2012, p. 40).

O drama de consciência que o atinge no final do romance, fruto de sua fraqueza moral diante de António Claro, é reflexo desse abandono ético da fase especular que o duplo proporciona: se o eu não tem certeza de que é um eu, minimamente estabelecido, não há compromisso ético possível. Traidor ou herói, herege ou santo, sonhador ou sonhado, tanto faz.

\footnotetext{
Pois quando tento captar este eu no qual me asseguro, quando tento defini-lo e resumi-lo, ele é apenas água que escorre entre meus dedos. Posso desenhar, um por um, todos os rostos que ele costuma assumir, todos também que lhe foram dados, esta educação, esta origem, este ardor ou estes silêncios, esta grandeza ou esta baixeza. Mas não se somam os rostos: este coração que é o meu permanecerá indefinível para sempre (CAMUS, 2005, p. 33).
}

Um corolário primeiro: a soma de eus possíveis não traz maior compreensão de si, muito pelo contrário, evidencia a impossibilidade de acabamento, de dar uma última palavra sobre si. A possibilidade de narrar a si mesmo e à História, evocada no romance, será objeto da próxima seção.

\section{Uma teoria da História}

“- Será que no estoy hecho a estar muerto, pero estos lugares y esta discusión me parecen un sueño, y no un sueño soñado por mí sino por otro, que está por nacer todavía".

Jorge Luis Borges, "Diálogo de muertos".

Discorreremos agora sobre um tema paralelo ao drama do duplo que vai sendo desenvolvi especialmente na metade inicial do romance, a saber: a teoria da História que esse professor defende há tempos no meio acadêmico (mesmo que de maneira informal). Na reunião docente de seu colégio, a teoria defendida por Tertuliano Máximo Afonso está resumida nestes simples termos:

Em minha opinião, disse ele, a única opção importante, a única decisão séria que será necessário tomar no que respeita ao conhecimento da História, é se deveremos ensiná-la de trás para diante ou, segundo a minha opinião, de 
diante para trás, todo o mais, não sendo despiciendo, está condicionado pela escolha que se fizer (SARAMAGO, 2008, p.40).

A teoria, assim apresentada, traria o intento de se evitar uma teleologia na qual o passado, sempre e necessariamente, iria apresentar os elementos que cumulativamente geraram os fatos posteriores até se chegar ao presente. É bem verdade, uma teleologia inversa não está excluída - e nem nos parece ser o caso de se fazê-lo -, uma vez que a finalidade (telos) parte do presente em direção ao passado: "de diante para trás".

A nós nos parece que Borges, no ensaio "Kafka y sus precursores", apresenta, implicitamente, um conceito de história semelhante a esse de Tertuliano, de modo que, ao aproximarmos tais esboços historiográficos, cremos que ambos se aclaram. Segundo o contista argentino, "cada escritor crea a sus propios precursores" (BORGES, 1980b, p. 228) ${ }^{34}$, pois passamos a, desde o presente, enxergar os elementos formais e temáticos passados com um quadro conceitual que só foi possível pelo presente. Deste modo, as situações e temas kafkianos por excelência vão sendo reconhecidos pelo ensaísta argentino na filosofia de Zenão de Eleia e nos escritos de Kierkegaard, por exemplo. Assim sendo, o presente não é necessariamente fruto do passado, mas, pelo contrário, o passado se destaca e passa a existir ${ }^{35}$ por causa do presente. De fato, é muito difícil ler o "Livro de Jó" e não inferir, ipso facto, uma leitura kafkiana ou mesmo mefistofélica. Do mesmo modo, não estaríamos propensos a enxergar um tom existencialista do século XX no livro de Eclesiastes?

Em verdade, temos uma atividade humana no tempo em questão, e esta atividade é tripartida, como já Santo Agostinho percebera no livro XI de suas Confissões. Quem percebeu com acuidade a importância da distentio animi agostiniana foi Paul Ricoeur, que em seu Tempo e Narrativa reúne as aporias do mythos aristotélico às do tempo, fenomenologicamente tomado, para formular uma compreensão ampla das relações entre tempo e história, tempo e narrativa, tempo-narrativa-ser (formulação essa que nos interessa diretamente neste artigo).

Paul Ricoeur, refletindo sobre a teoria do tempo de Santo Agostinho, expõe como o sujeito, envolto na esfera cristã de redenção e anelante da eternidade, relacionase com o tempo:

\begin{abstract}
Com efeito, é toda a dialética, interna ao próprio tempo, da intentio-distentio que é retomada sob o signo do contraste entre a eternidade e o tempo. Enquanto a distentio torna-se sinônimo da dispersão na multiplicidade e da errância do velho homem, a intentio tende a ser identificada com a reunião do homem interior ("Reúno-me seguindo o Uno", Ibid.). A intentio já não é a antecipação do poema inteiro antes da recitação que o faz transitar do futuro para o passado, mas a esperança das coisas últimas, na própria medida em que o passado a ser esquecido não é mais o que a memória recolheu, mas o emblema do velho homem segundo São Paulo em Filipenses 3, 12-14: "Assim, esquecendo o passado, voltado não paras as coisas futuras e transitórias, mas para aquelas que estão adiante e para as quais estou, não distendido, mas estendido (no distentus sed extensus), prossigo, num esforço, não de distensão (non secundum distentionem), mas de intenção (sed secundum intentionem), meu caminho rumo à palma à qual sou chamado lá no alto..." (ibid). (RICOEUR, 2010, p. 51).
\end{abstract}

O que Agostinho, citado por Ricoeur, está evidenciando é como o sujeito, que quer se unificar em meio à dispersão da multiplicidade, deve agir temporalmente para tal. Trata-se de considerar o passado enquanto velho homem, ao qual não mais pertence,

\footnotetext{
34 “Cada escritor cria os seus precursores".

${ }^{35}$ No sentido etimológico: ex sistere, estar/permanecer fora.
} 
ao mesmo tempo em que a atenção (attentio) ao presente é uma intentio visando ao futuro eterno e redentor. Evidentemente, esta passagem está inserida num contexto muito específico da doutrina moral cristã, trata-se da soteriologia agostiniana, ou seja, a doutrina da salvação que se reflete em uma teleologia ética - "a tristeza do finito com a celebração do absoluto" (RICOEUR, 2010, p. 52)

Uma vez que "O tempo existe na coisa narrada" (RICOEUR, 2010, p. 26), o ser só passa a existir na medida em que o tempo assim o permita, pois um ser, fora do tempo, está morto ou é Deus. Um raciocínio circular, aporético por excelência, como os espelhos e os duplos o são: "Agora a conversação vai repetir-se, o tempo arrependeu-se e voltou atrás" (SARAMAGO, 2008, p. 283). Pela força do narrar, o ser no tempo, num eterno retorno absolutamente cruel, reconduz o leitor às bifurcações de um novo romance que se vislumbra na última página deste (seria seu duplo metaficcional?): "O presente e a sucessão de presentes diante de uma alma permanentemente consciente, eis o ideal do homem absurdo" (CAMUS, 2005, pp.74-5).

O fato é que a compreensão possível de um personagem se dá no tempo, como Jean Pouillon elucida, em seu $O$ tempo no romance, estabelecendo assim a relação direta que há entre ser e tempo nos romances: "os personagens são vistos no tempo, mas este é mais do que o lugar dos mesmos: descrever esse tempo é revelar os personagens" (POUILLON, 1974, p. 23). Neste sentido, é possível, como movimento final deste tópico, reunir dialeticamente história, tempo e ser (de ficção ou não) sob o mesmo esquema analítico sugerido por Tertuliano e por Borges. Pouillon apresenta assim a nossa percepção: "Desde logo, não se pode dizer que a personalidade de um ser seja determinada estritamente pelo seu passado, visto ser ela, em seu presente, quem atribui um sentido a esse passado" (POUILLON, 1974, p. 130). "Kafka y sus precursores" e "a História de diante para trás": palavras-chave que se unem de maneira tensional no ato de narrar, no romance.

Assim sendo, não podemos nos furtar de discutir a respeito da linguagem no romance, pois é ela que proporciona tais representações temporal, ontológica e historiográfica. Mikhail Bakhtin surge como um teórico sobejamente adequado para sustentar e complementar essa discussão que envolve tempo, ser e narrativa; o narrar que rompe o mutismo. Bakhtin, em um rascunho coligido em Estética da criação verbal, traça a diferença entre silêncio e mutismo nestes termos, absolutamente coerentes com sua teoria dialógica da linguagem:

O silêncio e o som. Percepção do som (contra o fundo do silêncio). O silêncio e o mutismo (a ausência do som). A pausa e o início da palavra. A ruptura do silêncio pelo som é de natureza fisiológica e mecânica (condição da percepção), ao passo que a ruptura do mutismo pela palavra se relaciona com a pessoa e com o pensamento: é um mundo totalmente diferente. No silêncio, nada soa (não há algo que soe); no mutismo, ninguém fala (não há ninguém que fale). O mutismo só é possível no mundo humano (e possível somente para o homem). O silêncio e o mutismo são, claro, inteiramente relativos (BAKHTIN, 2003, p. 373) (grifos nossos).

Neste esboço reflexivo, o pensador russo demonstra o quão potente é a linguagem humana, dentro do viés dialógico por ele proposto. Só é possível tratar de mutismo na esfera humana, pois, mesmo sem dizer, algo está sendo dito: "Aquilo que certa literatura preguiçosa chamou durante muito tempo de silêncio eloquente não existe, os silêncios eloquentes são apenas palavras que ficaram atravessadas na garganta, palavras engasgadas que não puderam escapar ao aperto da glote" (SARAMAGO, 2008, p. 60). 


\section{O homem duplicado: da linguagem ao ser, do ser à linguagem}

\begin{abstract}
"Pensé con miedo: ¿dónde estoy? Y comprendí que no lo sabía. Pensé ¿quién soy? $Y$ no me pude reconocer. El miedo creció en mí. Pensé: Esta vigilia desconsolada ya es el Infierno, esta vigilia sin destino será mi eternidad. Entonces desperté de veras: temblando"
\end{abstract}

Jorge Luis Borges, "La duración del Infierno".

Levando-se em consideração o que já vimos, podemos produzir alguns corolários que nos possibilitarão aprofundar nossa análise neste tópico. $\mathrm{O}$ primeiro corolário é que a existência do duplo obriga o personagem a fazer uma profunda reflexão de ordem ontológica, na qual a percepção especular é vicariamente a experimentação do olhar do outro no mesmo. O segundo corolário, que se refere à teoria da História de Tertuliano, coloca o ser num eterno presente, em que o passado surgirá em relevo com as lentes possíveis do agora (daí a nossa analogia com o "triplo presente" agostiniano).

Cabe acrescentar que Tertuliano sugere uma aproximação desta sua teoria historiográfica à análise biográfica, quando diz:

Tertuliano Máximo Afonso regressou ao trabalho, pensando que, tal como na sua arrojada proposta para o estudo da História, também as vidas das pessoas poderiam ser contadas de diante para trás, esperar que chegassem ao seu fim para depois, pouco a pouco, ir remontando a corrente até ao brotar da fonte, identificando de caminho os cursos afluentes e navegar por eles acima (SARAMAGO, 2008, p.177).

Ora, mas não é essa, invariavelmente, a condição do narrador do romance? Por isso, Pouillon e Ricoeur sustentarão que uma análise do ser deve passar por uma mirada temporal. Contudo, é no narrar, é na linguagem que os dois corolários se unem tensionalmente. Não à toa, nesse romance Saramago produz dezenas de páginas reflexivas em torno das possibilidades e impossibilidades da linguagem: "Há coisas que nunca se poderão explicar por palavras" (SARAMAGO, 2008, p. 53).

É neste sentido que evocaremos, neste tópico, Mikhail Bakhtin, pois o russo destinou grande parte de suas elucubrações para rastrear a linguagem do romance, pois encontrou neste gênero uma aplicação de suas concepções de linguagem e do próprio ser. Segundo Bakhtin, "o que caracteriza o gênero romanesco não é a representação do homem em si, mas exatamente a representação da linguagem" (BAKHTIN, 2015, p. 128) (grifo do autor). Ora, se a representação operada no romance é da linguagem, a natureza desta é essencialmente social, feita de vozes alheias: "no discurso do dia a dia de qualquer pessoa que tem vida social, ao menos metade de todas as palavras que ela pronunciou são palavras alheias (apreendidas como alheias)" (BAKHTIN, 2015, p. 132). Assim sendo, a existência do duplo, entendida nestes termos, é a inescapável evidência do outro no mesmo, de que só é possível pensar em uma identidade dialógica, mas nunca monística. Por essa razão, em uma passagem famosa, o teórico russo dirá que diante do espelho "nunca estamos sós": 
A visão que temos de nosso aspecto físico quando nos olhamos no espelho é de natureza totalmente particular. Visivelmente, vemo-nos sem mediação. Ora, não é nada disso; permanecemos em nós mesmos e só vemos o nosso reflexo, um reflexo que não poderia, de maneira imediata, tornar-se um componente de nossa visão e de nossa vivência do mundo: vemos o reflexo de nosso aspecto físico, mas não vemos a nós mesmos em nosso aspecto físico, o aspecto físico não nos engloba por inteiro, estamos diante do espelho, mas não estamos dentro do espelho; o espelho só pode fornecer o material de uma auto-objetivação — um material que não é, para ser exato, sequer um material. De fato, nossa situação na frente do espelho sempre é deturpada, pois, na ausência de um meio de abordagem de nós mesmos, também nesse caso identificamo-nos com o outro possível, indeterminado, com cuja ajuda tentamos encontrar uma posição de valores a respeito de nós mesmos; ou seja, é a partir do outro que, mais uma vez, tentamos dar-nos vida e forma; daí essa expressão particular de nosso rosto tal como a vemos no espelho e que não temos na vida (BAKHTIN, 2003, p. 52).

É, precisamente, esta sensação de olhar-se pelos olhos do outro que Tertuliano experimenta, logo quando descobre a existência de seu duplo:

Olhava-se ao espelho como quem se olha ao espelho apenas para avaliar os estragos de uma noite mal dormida, nisso pensava e em nada mais, quando, de súbito, a desafortunada reflexão do narrador sobre os traços físicos e a problemática eventualidade de que em um dia futuro, auxiliados pela demonstração de talento suficiente, poderiam vir a ser postos ao serviço da arte teatral ou da arte cinematográfica, desencadeou nele uma reacção que não será exagero classificar de terrível. Se aquele tipo que fez de empregado da recepção aqui estivesse, pensou dramaticamente, se estive aqui diante deste espelho, a cara que de si mesmo veria seria esta (SARAMAGO, 2008, p. 30).

Importante apontar que o outro evocado ali diante do espelho é o personagem interpretado por Daniel Santa-Clara, ou seja, uma máscara deste outro eu de que só se tem uma imagem ${ }^{36}$. Tertuliano conhece seu outro a partir de imagens emprestadas de outros eus, que é a própria definição de ser ator: utilizar máscaras para a representação de uma identidade. Quando descobre o nome deste ator, Daniel Santa-Clara, ainda não sabe que trata-se de um pseudônimo, e que se chama António Claro. Este resquício identitário já é suficiente para que a necessidade do olhar do outro sobre o mesmo se torne evidente: "É nesse sentido que o homem tem uma necessidade estética absoluta do outro, da sua visão e da sua memória que o junta e o unifica e que é a única capaz de lhe proporcionar um acabamento externo. Nossa individualidade não teria existência se o outro não a criasse" (BAKHTIN, 2003, p. 55).

No primeiro encontro pessoal, Tertuliano expõe a condição de estrangeiridade que permeia (e permeará) a relação destes idênticos estranhos: "quanto a isso que diz, de não me conhecer, permito-me objectar que estamos na mesma posição, é certo que a mim nunca me viu, mas eu, até agora, só o vi a si como aquilo que não é, a representar personagens, portanto estamos empatados" (SARAMAGO, 2008, p. 174).

Após se disfarçar diante do espelho, Tertuliano

Quando pela primeira vez olhou a sua nova fisionomia sentiu um fortíssimo impacte interior, aquela íntima e insistente palpitação nervosa do plexo solar

\footnotetext{
36 "Pois sua arte é isso, fingir totalmente, entrar o mais fundo possível em vidas que não são as dele. Ao cabo desse esforço fica clara sua vocação: aplicar-se de corpo e alma a não ser nada ou a ser muitos" (CAMUS, 2004, p. 93).
} 
que tão bem conhece, porém, o choque não tinha sido o resultado, simplesmente, de se ver distinto do que era antes, mas sim, e isso é muito mais interessante se tivermos em conta a peculiar situação em que tem vivido nos últimos tempos, uma consciência também distinta de si mesmo, como se, finalmente, tivesse acabado de encontrar-se com a sua própria e autêntica identidade. Era como se, por aparecer diferente, se tivesse tornado mais ele mesmo (SARAMAGO, 2008, p. 146).

O professor de história experimenta a máscara, característica do ator, e, neste momento, engana-se a si mesmo sentindo ter encontrado alguma essência una dentro de si. Contudo, a cena toda é farsesca na medida em que o disfarce só evidencia a impossibilidade de haver um só eu por trás dos bigodes falsos ${ }^{37}$.

É bem verdade, porque o ofício do ator assim o exige, António Claro parece ter mais clara em si a condição do ser humano, na linha da discussão ora promovida, a saber: um composto híbrido de eus que se alternam na boca de cena, que é a própria consciência. Não isento de um tom angustiado, Albert Camus discorre sobre essa condição nestes termos:

Basta, então, um pouco de imaginação para perceber o que significa um destino de ator. Um ator compõe e enumera no tempo seus personagens. E também no tempo aprende a dominá-los. Quanto mais vidas diferentes ele viveu, com mais facilidade se separa delas. Chega a hora em que tem que morrer em cena e no mundo. O que viveu está à sua frente. Ele vê com clareza. Sente o que essa aventura tem de dilacerante e de insubstituível. Sabe disso e agora pode morrer. (CAMUS, 2004, p. 97).

Em verdade, o ofício de ator acaba reforçando ainda mais a presença metaficcional no romance de Saramago, da mesma forma que a mãe de Tertuliano é uma leitora de romances triviais. O leitor acaba por ver a si mesmo enquanto leitor de ficção a todo o momento, mas não de um modo somente auto-referencial, como é comum na ficção pós-moderna:

Daniel Santa-Clara, em rigor, não existe, é uma sombra, um títere, um vulto variável que se agita e fala dentro de uma cassete de vídeo e que regressa ao silêncio e à imobilidade quando acaba o papel que lhe ensinaram, ao passo que o outro, esse António Claro, é real, concreto, tão consistente como Tertuliano Máximo Afonso (SARAMAGO, 2008, p. 141).

Esta oposição fingida entre Santa-Clara/António Claro converte, como resultado metaficcional especular, o ente de ficção em um duplo do leitor, na qual este último se reconhece em seu esforço de expressar sua humanidade: "Estive com ele, e agora não sei quem sou" (SARAMAGO, 2008, p.187). E não poderia ser diferente, pois, como Bakhtin diz em Problemas da poética de Dostoiévski: "A atitude do herói face a si mesmo é inseparável da atitude do outro em relação a ele. A consciência de si mesmo fá-lo sentir-se constantemente no fundo da consciência que o outro tem dele, 'o eu para si' no fundo do 'o eu para o outro'. Por isso o discurso do herói sobre si mesmo se constrói sob a influência direta do discurso do outro sobre ele" (BAKHTIN, 1997, p. 208).

James Wood, comentando sobre $O$ ano da morte de Ricardo Reis, contrapõe a ficção de Saramago à dita "pós-moderno", sustentando que o jogo metaficcional é mais

\footnotetext{
${ }^{37}$ Assim diz o senso comum (voz alegórica do romance) a Tertuliano: "Quanto mais te disfarçares, mais te parecerás a ti próprio" (SARAMAGO, 2008, p. 139).
} 
sutil, menos de papel e mais humano do que se supõe: "ele [Saramago] pode nos intrigar com algo que já sabemos, ou seja, que Ricardo Reis é fictício. Saramago faz disso algo profundo e comovente, porque o próprio Ricardo também se sente um tanto fictício, no máximo um espectador à sombra, um homem à margem das coisas. E, quando Ricardo Reis reflete sobre isso, sentimos uma estranha ternura por ele, cientes de algo que ele não sabe - que ele não é real" (WOOD, 2012, p.97). Mutatis mutandis, o leitor se depara com o mesmo drama em $O$ homem duplicado, pois, desde o início da descoberta, Tertuliano passa a se perguntar quem seria o "original" e quem seria a cópia. Ora, trata-se de saber quem tem a primazia do ser e quem é um simulacro. Sobre isso, começa perguntando António Claro: "E que importância terá dizermos um ao outro a hora a que viemos ao mundo, A importância que irá ter é que ficaremos a saber qual de nós dois, você ou eu, é o duplicado do outro" (SARAMAGO, 2008, p. 194). "O duplicado é você" dirá António Claro mais tarde, o que trará grande desolação ao professor de história, precisamente como ocorre com o protagonista do conto "Ruínas circulares", de Jorge Luis Borges. Eis o momento final: "Caminó contra los jirones de fuego. Estos no mordieron su carne, éstos lo acariciaron y lo inundaron sin calor y sin combustión. Con alivio, con humillación, con terror, comprendió que él también era una apariencia, que otro estaba soñándolo" (BORGES, 1980a, p. 440).

Com esta possibilidade reflexiva que só o duplo nos proporciona, concluímos que a pergunta não faz sentido, pois as respostas serão sempre tautológicas ("o ser é o ser", dirá a ontologia), restando somente a fé que existimos:

\begin{abstract}
Será que todos nós, de alguma maneira, somos personagens fictícios, gerados pela e escritos por nós mesmos? É uma pergunta semelhante à de Saramago; mas vale notar que ele chega à sua pergunta percorrendo o caminho oposto ao daqueles romancistas pós-modernos que gostam de nos lembrar da metaficcionalidade de todas as coisas. [...] Começando com um personagem inventado, porém, Saramago consegue atravessar o mesmo ceticismo, mas em direção contrária, rumo à realidade, às questões mais profundas. Com efeito, ele pergunta: mas o que é "só um personagem"? E a incerteza de Saramago é mais real do que o ceticismo de William Gass, pois ninguém na vida diz "eu não existo". Pelo contrário, dizemos: "Acredito que existo", exatamente como faz Ricardo (WOOD, 2012, p. 98).
\end{abstract}

Os exercícios metaficcionais acabam se tornando meios pelos quais o narrador nos apresenta Tertuliano desde o ponto de vista mais objetivamente afastado possível: o nível do livro, do papel, da engrenagem composicional que dá vida a este ente de ficção sabidamente desta categoria ontológica, mas que nos joga violentamente ao mundo real, via leitor, por sua ação especular" ${ }^{39}$, pois: "Provavelmente, ler também é uma forma de estar lá" (SARAMAGO, 2008, p. 72).

Deste modo, encerramos esta ruína circular, encontrando do outro lado a nós mesmos. Se um dia Platão expulsou os poetas por escreverem "mentira sobre mentira", os arranjos metaficcionais adicionam uma camada a mais deste ardil. Contudo, o resultado, em Saramago, é um retorno drástico à realidade, pois reabilita o mundo por meio do leitor.

\footnotetext{
38 “Caminhou contra as línguas de fogo. Estas não morderam sua carne, estas o acariciaram e o inundaram sem calor e sem combustão. Com alívio, com humilhação, com terror, compreendeu que ele também era uma aparência, que outro o estava sonhando".

${ }^{39}$ Vincent Jouve, em A leitura, dirá que certas obras, as mais duradouras, operam uma "redescoberta de si" durante sua leitura. Os termos que ele utiliza para descrever tal redescoberta estão em absoluta consonância com que vimos discutindo aqui: "O que a leitura permite, portanto, é a descoberta de sua alteridade. O 'outro' do texto, seja do narrador seja de uma personagem, sempre nos manda de volta, por refração, uma imagem de nós mesmos” (JOUVE, 2002, p.132).
} 


\title{
5. Quebra-se o espelho
}

\author{
"Un fugitivo no se oculta en un laberinto. No \\ erige un laberinto sobre un alto lugar de la \\ costa, un laberinto carmesí que avistan desde \\ lejos los marineros. No precisa erigir un \\ laberinto, cuando el universo ya lo es" \\ Jorge Luis Borges, "Abenjacán el Bojari, \\ muerto en su laberinto".
}

No ensaio "El sueño de Coleridge", Borges discorre sobre o crítico e poeta inglês, que teria sonhado o fragmento lírico Kubla Khan, o qual versa sobre um palácio mongol. $\mathrm{O}$ fato curioso é que, sem Coleridge saber (pois a publicação que revelaria isso viria vinte anos depois do poema), este palácio havia sido construído a partir de um sonho muito detalhado que Kubla Kahn teve. Assim conclui Borges o ensaio:

\begin{abstract}
Al primer soñador le fue deparada en la noche la visión del palacio y lo construyó; al segundo, que no supo del sueño del anterior, el poema sobre el palacio. Si no marra el esquema, alguien, en una noche de la que nos apartan los siglos, soñará el mismo sueño y no sospechará que otros lo soñaron y le dará la forma de un mármol o de una música. Quizá la serie de los suẽ̃os no tenga fin, quizá la clave esté en el último (BORGES, 1980b, p. $145) .^{40}$
\end{abstract}

Quem sabe a chave esteja no tempo, aos quais os seres e a linguagem se agarram em busca de significado existencial. O fato é que $O$ homem duplicado parece conservar chaves sempre provisórias para sua compreensão, pois o final que aponta para um reinício - espécie de serpente de Uroboro, à maneira de certo romancista de Cordisburgo -, ilustrando um eterno retorno que anula uma teleologia centrípeta. Por essa razão, escolhemos o olhar ensaístico centrífugo.

A presença borgiana, a base bakhtiniana e as ilações filosóficas de Camus e Lavelle foram os meios pelos quais buscamos enriquecer de sentidos possíveis a compreensão da obra de Saramago. De certo modo, o expediente metaficcional, tão utilizado no romance em questão, convoca uma leitura ora filosófica, ora apropriando-se da própria ficção, aproximada por um viés ensaístico.

Neste périplo de duas mãos, em que o homem é visto por todos os lados possíveis, além de estar duplicado diante de nossos olhos, saímos deste romance impossibilitados de qualquer finalização - "acabamento", na conceituação de Bakhtin -, evidenciando o que Albert Camus afirma: "O fosso entre a certeza que tenho da minha existência e o conteúdo que tento dar a esta segurança jamais será superado. Para sempre serei estranho a mim mesmo" (CAMUS, 2005, p. 33).

Quem é esse no espelho?

\footnotetext{
40 “Ao primeiro sonhador lhe foi deparada na noite a visão do palácio e o construiu; ao segundo, que não soube do sonho do anterior, o poema sobre o palácio. Se não falha o esquema, alguém, numa noite da que nos afastam os séculos, sonhará o mesmo sonho e não suspeitará que outros o sonharam e lhe dará a forma de um mármore ou de uma música. Quem sabe a série dos sonhos não tenha fim, quem sabe a chave esteja no último."
} 


\section{REFERÊNCIAS:}

BAKHTIN, Mikhail. Teoria do romance I: A estilística. Tradução, prefácio, notas e glossário de Paulo Bezerra; organização da edição russa de Serguei Botcharov e Vadin Kójinov. São Paulo: Editora 34, 2015.

Problemas da Poética de Dostoiévski. Trad. Paulo Bezerra. Rio de Janeiro: Forense Universitária, 1997.

2003. Estética da criação verbal. Trad. Paulo Bezerra. São Paulo: Martins Fontes,

BORGES, Jorge Luis. Prosa completa (Volumen I). Bruguera: Barcelona, 1980a. Prosa completa (Volumen II). Bruguera: Barcelona, 1980b.

CAMUS, Albert. $O$ mito de Sísifo. Tradução de Ari Roitman e Paulina Watch. Rio de Janeiro: Record, 2005.

FOUCAULT, Michel. "Outros espaços". In: Ditos e escritos III - Estética: Literatura e pintura, música e cinema. Trad. Inês Autran Dourado Barbosa. Rio de Janeiro: Forense Universitária, 2003.

JOUVE, Vincent. A leitura. Trad.: Brigitte Hervot. São Paulo: Editora UNESP, 2002.

LAVELLE, Louis. O erro de Narciso. Trad. Paulo Neves. São Paulo: É Realizações, 2012.

POUILLON, Jean. O tempo no romance. Trad. Heloysa de Lima Dantas. São Paulo: Ed. Cultrix, 1984.

RICOEUR, Paul. Tempo e Narrativa (Vol.I: A intriga e a narrativa histórica). Trad. Claudia Berliner. São Paulo: Editora WMF Martins Fontes, 2010.

SARAMAGO, José. O homem duplicado. São Paulo: Companhia das Letras, 2008.

WOOD, James. Como funciona a ficção. Trad. Denise Bottmann. São Paulo: Cosac Naify, 2012. 